\title{
PEMANFAATAN MODEL SAEPADU UNTUK MENINGKATKAN MOTIVASI DAN HASIL BELAJAR IPA BAGI PESERTA DIDIK KELAS VIII E SMP NEGERI 2 BOJONGSARI SEMESTER 2 TAHUN PELAJARAN 2019/2020
}

\author{
NOKMAN RIYANTO \\ UIN Prof. K.H. Saifuddin Zuhri Purwokerto \\ e-mail: nokman.riyanto@gmail.com
}

\begin{abstract}
ABSTRAK
Penelitian ini merupakan upaya dalam meningkatkan motivasi dan hasil belajar IPA dengan memanfaatkan model Saepadu pada peserta didik kelas VIII E SMP Negeri 2 Bojongsari Kabupaten Purbalingga. Tujuan dari penelitian ini adalah mengetahui sejauh mana proses pembelajaran dengan memanfaatkan model Saepadu di kelas VIII E untuk meningkatkan motivasi dan hasil belajar IPA. Adapun penelitian ini merupakan penelitian tindakan kelas (PTK). Langkah-langkah dalam penelitian tindakan ini meliputi perencanaan, pelaksanaan, observasi, dan refleksi. Pengumpulan data penelitian menggunakan instrumen tes dan non tes serta kuesioner. Kuesiner tersebut digunakan untuk data rasional yang nantinya divalidasi datanya dengan analisis data rasional. Pelaksanaan penelitian ini berdasarkan sintaks pembelajaran model saepadu. Berdasarkan dari data penelitian menunjukkan hasil bahwa dengan pemanfaatan model saepadu dapat meningkatkan motivasi belajar peserta didik, yaitu sebesar 0,22 poin atau sekitar 6,49\% dari pra siklus hingga siklus I dan pada siklus I ke di Siklus II juga terjadi peningkatan 0,41 poin atau $11,36 \%$. Dengan menggunakan pembelajaran dengan model SAEPADU ini juga dapat meningkatkan hasil belajar IPA pra siklus dibandingkan pada siklus I yaitu 28,5 atau sebesar $76,62 \%$ dengan jumlah peserta didik yang lulus KKM mengalami peningkatan sebesar $43,34 \%$. Sedangkan untuk hasil rata-rata nilai ter tertulis IPA siklus I dibandingkan pada siklus II yaitu 9,5 sebesar 14,18\%.. Kesimpulannya terjadi peningkatan motivasi dan hasil belajar peserta didik dengan memanfaatkan model Saepadu.
\end{abstract}

Kata kunci : Model Saepadu, Motivasi, Hasil Belajar

\section{ABSTRACT}

This research is an effort to increase motivation and science learning outcomes by utilizing the Saepadu model in class VIII E students of SMP Negeri 2 Bojongsari, Purbalingga Regency. The purpose of this study was to determine the extent of the learning process by utilizing the Saepadu model in class VIII E to increase motivation and science learning outcomes. This research is a classroom action research (CAR). The steps in this action research include planning, implementation, observation, and reflection. Collecting research data using test and non-test instruments and questionnaires. The questionnaire is used for rational data which will later be validated with rational data analysis. The implementation of this research is based on the learning syntax of the Saepadu model. Based on the research data, the results show that using the Saepadu model can increase students' learning motivation, which is 0.22 points or about $6.49 \%$ from pre-cycle to cycle I and in cycle I to Cycle II there is also an increase of 0.41 points or $11.36 \%$. By using learning with the SAEPADU model, it can also improve pre-cycle science learning outcomes compared to the first cycle, namely 28.5 or $76.62 \%$ with the number of students who passed the KKM increased by $43.34 \%$. Meanwhile, the average written score for science in the first cycle compared to the second cycle was 9.5 by $14.18 \%$. In conclusion, there was an increase in students' motivation and learning outcomes by utilizing the Saepadu model.

Keywords: Saepadu Model, Motivation, Learning Outcomes

\section{PENDAHULUAN}

Pendidikan merupakan modal dasar jangka panjang bahwa bilamana dikelola dengan baik dapat membangun eksistensi suatu negara. Pengajaran merupakan wadah bagi peserta 
didik untuk mencari informasi, menumbuhkembangkan potensi yang dimilikinya baik potensi skolastik maupun potensi non akademik. Interaksi instruktif tidak dapat dipisahkan dari siklus perbaikan itu sendiri. Peningkatan dalam proses pendidikan dibimbing dan dimaksudkan untuk menumbuhkan SDM yang berkualitas (Ariani, T, 2017).

Pembelajaran di sekolah akan lebih bermakna apabila peserta didik diajak untuk lebih menerapkan pembelajaran langsung serta kontekstual. Peserta didik yang mampu mengolah setiap pelajaran dalam proses pembelajaran menjadi sebuah kompetensi merupakan keberhasilan dalam penguasaan konsep di bidang pendidikan. Dalam pembelajaran sekarang ini tentunya diarahkan pada pembelajaran yang mampu menerapkan pola berpikir tingkat tinggi dan penguasaan literasi.

Pada pembelajaran berbasis berpikir tingkat tinggi ini dapat dikatakan membawa keberhasilan apabila seorang peserta didik dapat menerapkan konsep penguasaan materi tidak hanya dalam tataran mengingat dan memahami saja, akan tetapi peserta didik harus mampu menganalisis, mensintesis, mengevaluasi hingga mengkreasikan suatu konsep pembelajaran yang meraka pelajari. Dalam penguasaan literasi juga demikian, peserta didik harus mampu menguasai tidak hanya penerapan literasi dasar saja tetapi harus mampu menguasari literasi yang lain seperti literasi informasi, literasi sains dan lainnya.

Berdasarkan hasil Programme for International Student Assessment (PISA) untuk Indonesia tahun 2018 menunjukkan bahwa skor rata-rata Indonesia pada angka 371 masih di bawah rerata negara-negara anggota OECD di angka 487. Tren penguasaan membaca peserta didik Indonesia di skor 371, untuk penguasaan matematika peserta didik Indonesia di skor 379 dan untuk penguasaan sains peserta didik Indonesia di skor 396.

Berdasarkan hasil tersebut menggambarkan bahwa peserta didik di Indonesia masih rendah dalam kemampuan kecakapan IPA, antara lain: mengenali masalah yang bersifat ilmiah, memanfaatkan realitas logis/ilmiah, berkonsentrasi pada kerangka kehidupan dan memahami pemanfaatan perangkat keras IPA. Informasi tersebut menunjukkan kebenaran pendidikan IPA yang masih rendah di Indonesia.

Hal tersebut nyata adanya dengan rerata nilai pra pembelajaran IPA peserta didik pada kelas VIII E SMP Negeri 2 Bojongsari tahun pelajaran 2019/2020 yaitu 38,50. Belum optimalnya pembelajaran IPA ini tidak hanya didapatkan dari beberapa publikasi ilmiah namun secara nyata di SMP Negeri 2 Bojongsari sendiri juga demikian. Bukan hanya dari segi kemampuan kognitif (pengetahuan) tetapi juga secara aspek sikap dan keterampilan juga demikian. Hal ini dapat di lihat pada beberapa hasil Ulangan Harian dan Ulangan semester yang nilainya tidak jauh beda dengan nilai Ujian Nasional.

Salah satu yang menyebabkan kurangnya nilai setiap aspek tersebut adalah karena peneliti belum menggunakan secara maksimal pola pembelajaran yang bervariasi. Hal ini dapat ditunjukkan dengan masih sedikitnya pembelajaran yang memanfaatkan model pembelajaran yang ada di kurikulum 2013. Pembelajaran hanya dilakukan secara monoton dengan tatap muka di kelas. Padahal apabila melihat model-model yang digunakan dalam kurikulum 2013 ini sangat bervariasi seperti model inquiri, penemuan, pembelajaran berbasis masalah dan pembelajaran berbasis proyek. Model-model yang digunakan tersebut harusnya sesuai dengan pendekatan saintifik. Akan tetapi, masih banyak peluang dalam pengembangan model pembelajaran baru yang dapat menjawab masalah-masalah yang situasional berkaitan dengan pembelajaran sebagai penerapam kurikulum 2013 di Indonesia.

Menurut Brookhart (2010) peserta didik perlu mengembangkan berbagai macam kemampuan untuk menjawab tantangan abad 21 seperti kemampuan penalaran tingkat tinggi termasuk penalaran dasar, penalaran inovatif, berpikir kritis, dan dinamis dalam membuat keputusan.

Pembelajaran IPA seharusnya memiliki pilihan untuk menjadi bekal bagi peserta didik dengan kemampuan mengatasi masalah (berpikir kritis), memiliki pilihan untuk menangani masalah dalam kehidupan sehari-hari di masyarakat. Pembelajaran IPA sangatlah penting dalam semua aspek kehidupan, karena harus diwujudkan agar seluruh masyarakat Indonesia 


\section{SCIENCE : Jurnal Inovasi Pendidikan Matematika dan IPA Vol. 1 No. 3 November 2021 e-ISSN : 2797-1031 | p-ISSN : 2797-0744}

menguasai ilmu pengetahuan, guna membentuk masyarakat luas yang berpendidikan IPA sekaligus memiliki kepribadian bernegara. Peningkatan Pelatihan IPA bertanggung jawab atas tercapainya pendidikan sains generasi muda tanah air, oleh karena itu harus terus digarap agar semakin berkualitas. Peningkatan kualitas pembelajaran IPA dilakukan melalui proses pemikiran sains atau peningkatan kemampuan sains konvensional. Pendidik IPA yang mahir diperlukan untuk memahami dan menerapkan penyusunan rencana pendidikan, substansi keilmuan, substansi edukatif, dan penilaian (appraisal) yang mengacu pada IPA.

Penguasaan kemampuan IPA tidak terlepas dengan adanya motivasi dan hasil belajar yang memadai di sekolah. Hasil belajar adalah bagian utama dari proses pembelajaran. Nana Sudjana (2009: 3) mencirikan hasil belajar peserta didik pada dasarnya adalah perubahan tingkah laku sebagai hasil belajar dari perspektif yang lebih luas meliputi bidang intelektual atau kognitif, emosional atau afektif, serta psikomotorik. Dimyati dan Mudjiono (2006: 3-4) juga melihat bahwa hasil belajar merupakan konsekuensi dari asosiasi belajar dan mendidik.

Motivasi berasal dari kata motif yakni suatu keadaan yang merupakan kondisi yang terjadi dalam seseorang yang memberikan dorongan agar orang untuk melakukan latihan tertentu dengan sengaja atau tidak untuk mencapai tujuan tertentu (Winarni, Anjariah, dan Romas, 2016). motivasi belajar dapat dicirikan sebagai dorongan utama untuk melakukan latihan-latihan khusus yang berasal dari dalam diri dan lebih jauh lagi dari luar individu untuk mengembangkan semangat belajar (Monika dan Adman, 2017).

Berkaca pada beberapa permasalahan yang telah telah diuraikan di atas, maka dapat dikatakan bahwa perlu diterapkan pembelajaran inovatif dalam pembelajaran IPA. Pembelajaran inovatif dapat dilakukan dengan menerapkan model SAEPADU. SAEPADU merupakan akronim dari kata dalam bahasa Inggris, antara lain $\underline{s} t u d y$ it, $\underline{a}$ nalyzing subject, $\underline{\boldsymbol{e}}$ ksploration with literature, presentation, aplication, duplication. Model saepadu ini merupakan pengembangan model yang mengupayakan penguasaan beberapa aspek dan kompetensi seperti penguasaan literasi, mumerasi, komunikasi, kolaborasi serta menerapkan pembelajaran berpikir tingkat tinggi.

\section{METODE PENELITIAN}

Penelitian ini memanfaatkan gagasan penelitian tindakan kelas secara keseluruhan. Metode Pelaksanaan penelitian tindakan ini sebagaimana dikemukakan oleh Wardani (2002: 24) mengemukakan bahwa langkah-langkah penelitian ini adalah: 1). perencanaan, 2). pelaksanaan, 3). Pengamatan/observasi, 4). Refleksi. Hasil dari proses refleksi atas kegiatan yang diambil akan dimanfaatkan kembali untuk mengubah rencana yang telah dibuat jika kebetulan kegiatan yang diambil tidak berhasil dalam menangani masalah tersebut.

Untuk mengatasi permasalahan rendahnya motivasi dan hasil belajar IPA peserta didik di SMP Negeri 2 Bojongsari, maka penting untuk mengatasi permasalahan dalam proses pembelajaran IPA dengan memanfaatkan model pembelajaran SAEPADU setelah pra siklus, peningkatan yang ideal belum sesuai dengan indikator yang harus dicapai.

Adapun pelaksanaan penelitian tindakan kelas (PTK) ini dilaksanakan sebanyak 2 siklus, dengan dua kali pertemuan dan 1 kali kegiatan penilaian dalam masing-masing siklus. Pada tahap perencanaan terdiri dari beberapa kegiatan berikut: 1) Mengkaji ulang RPP (Rencana Pelaksanaan Pembelajaran) beserta skenario yang akan dilaksanakan, 2) Menyiapkan media pembelajaran, mencoba dan menstimulasikan dengan teman sejawat, 3) Mencari hambatanhambatan proses belajar mengajar beserta mencari solusi bagaimana cara mengantisipasi jika hal tersebut terjadi, 4) Membuat dan mempersiapkan perangkat pengumpul data seperti lembar observasi, lembar kerja peserta didik (LKPD), kuesioner 5) mempersiapkan rekan sejawat untuk siap mengobservasi dalam proses pembelajaran pada saat penelitian dilaksanakan.

Perangkat pengumpul data dan informasi peningkatan pelaksanaan proses pembelajaran melalui kegiatan penelitian tindakan kelas (PTK) ini terdiri dari: 1). Survei untuk menggambarkan informasi motivasi belajar siswa, 2). Tes tertulis untuk menemukan informasi 
mengenai hasil belajar peserta didik, 3). Lembar kuesioner untuk mengetahui informasi wawasan dan dampak siswa terhadap pemanfaatan model pembelajaran SAEPADU.

Indikator keberhasilan dalam penelitian ini yaitu hasil belajar peserta didik memiliki persentase tuntas klasikal sekurang-kurangnya $85 \%$ dengan rata-rata kelas sekurang-kurangnya 70 berdasarkan KKM mata pelajaran IPA (Mulyasa, E. 2008: 101-2) sedangkan untuk indikator motivasi peserta didik minimal baik.

\section{HASIL PENELITIAN}

\section{Deskripsi Kondisi Awal}

SMP Negeri 2 Bojongsari yang lokasinya di daerah pedesaan kabupaten Purbalingga merupakan sekolah yang cukup sarana pembelajaran IPA. Berikut kami sampaikan hasil observasi awal terhadap kegiatan pembelajaran IPA di kelas VIII E SMP Negeri 2 Bojongsari sebagai berikut:

a. Dari segi persiapan guru dan peserta didik sudah baik, namun pada rencana pelaksanaan pembelajarannya belum dilengkapi dengan kisi-kisi soal dan kriteria penilaiannya.

b. Motivasi peserta didik dalam proses pembelajaran pada umumnya kurang terhadap mata pelajaran IPA, karena dianggap mata pelajaran IPA adalah momok sebagai pelajaran yang susah.

c. Pembelajaran belum melibatkan peserta didik secara menyeluruh dan masih berpusat pada guru semata.

d. Pembelajaran masih monoton dan belum mengguanakan media atau model pembelajaran yang lain.

e. Peserta didik belum melakukan motivasi yang bersifat konstruktivistik karena hanya duduk, mendengarkan dan mencatat informasi, kemudian mengerjakan tugas yang disampaikan guru.

f. Belum menerapkan penilaian yang bersifat psikomotor atau aspek keterampilan sehingga kurang komprehensif.

g. Masih banyak peserta didik yang mengantuk, berbicara sendiri, dan mengganggu temannya.

Berdasarkan hasil orbservasi awal inilah yang akan digunakan sebagai bahan diskusi antara peneliti dan observer. Dari hasil diskusi bersama observer bahwa pembelajaran IPA di kelas VIII E masih bersifat monoton. Hal ini dikarenakan lebih mengedepankan pembelajaran dengan model ceramah yang tidak didukung dengan adanya model dan media pembelajaran yang lain sehingga guru selaku fasilitator pembelajaran belum melakukan tugasnya dengan baik.

Peserta didik merasa kurang menyenangi dan memiliki penilaian atau sikap yang negatif terhadap mata pelajaran IPA. Mereka juga memberikan istilah mata pelajaran IPA dengan berbagai macam istilah seperti mata pelajaran yang paling membuat bosan, pelajaran yang memiliki momok sulit, oleh karena itu sebagian besar peserta didik yang kurang tertarik, sehingga hasil belajar menjadi rendah, hal tersebut ditemukan pada hasil belajar pada hasil pra siklus dalam penelitian ini yaitu nilai rata-rata ulangan harian: 38,50 dengan persentase peserta yang tuntas belajar: 3,3\%, selain itu motivasi belajar peserta didik juga rendah, hal ini dapat diketahui dari angket motivasi setelah pembelajaran sebelum tindakan yang ditunjukkan pada grafik 1 . 


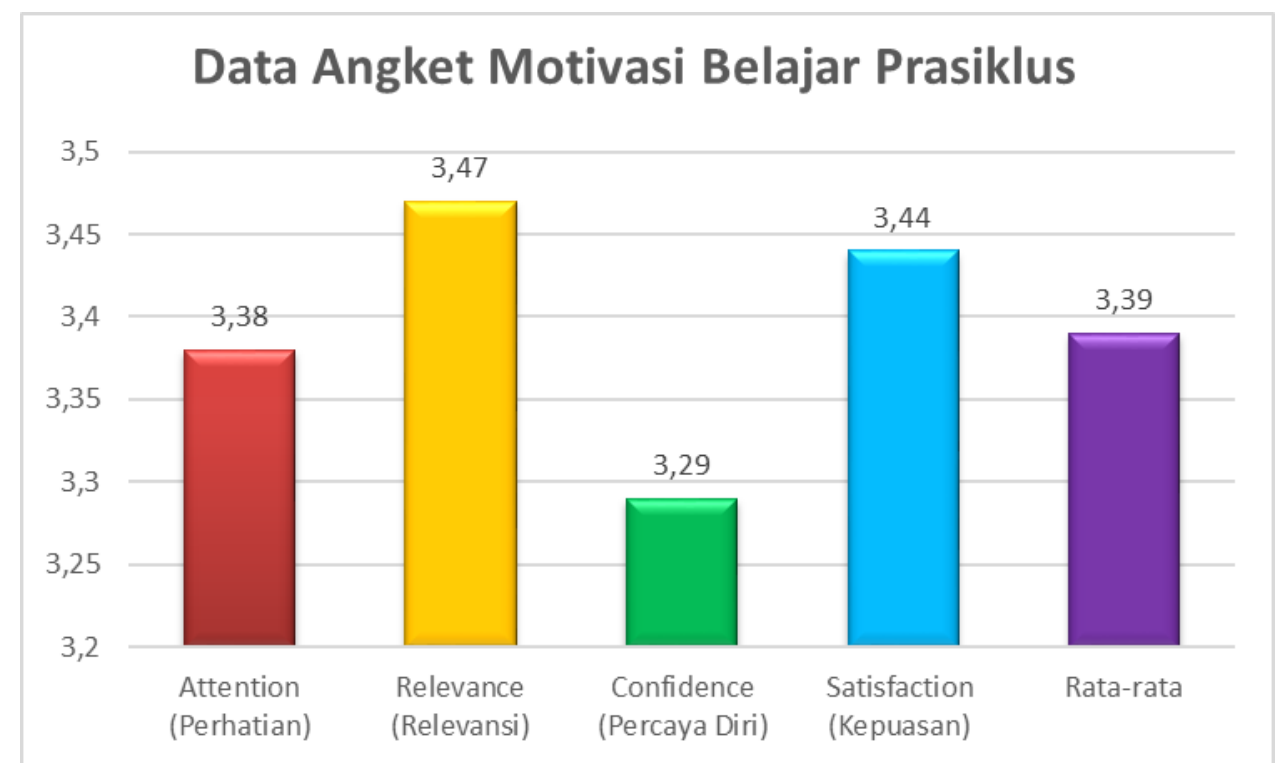

Gambar 1. Grafik Data motivasi Pra Siklus

Dengan penelitian ini peneliti memiliki tujuan untuk meningkatkan pembelajaran yang memiliki kualitas serta memberi peningkatan pada motivasi dan hasil belajar peserta didik melalui model yang masih baru yaitu model SAEPADU. Model ini merupakan hasil pengembangan terhadap model STEM yang terintegrasi dengan pengembangan literasi peserta didik yang digunakan untuk mengatasi masalah pembelajaran di kelas VIII E dengan melakukan penelitian tindakan kelas. Model ini memberikan semangat peneliti untuk mengubah pola pembelajaran dan pengembangan literasi di kelas dan tujuan akhirnya pencapaian kompetensi peserta didik dapat tercapai dengan hasil belajar yang meningkat.

Langkah-langkah penelitian tindakan untuk memecahkan permasalahan pembelajaran sebagai berikut:

a. Guru menyusun perencanaan pembelajaran dengan membuat RPP dengan model SAEPADU yang disertai dengan penilaian untuk menggambarkan sejauhmana hasil belajar peserta didik serta membuat angket untuk menelusuri motivasi peserta didik.

b. Dalam menyajikan materi guru menggunakan model SAEPADU berbantuan alat-alat yang dapat diperoleh peserta didik di rumahnya yang berisi tentang materi pelajaran IPA yang akan dipelajari di dalam kelas.

c. Guru lebih banyak memberdayakan peserta didik agar peserta didik dapat aktif dan berperan serta dalam proses pembelajaran sehingga aspek student centered dapat dilaksanakan serta berperan sebagai fasilitator.

d. Guru melakukan penilaian yang berbasis kelas atau penilaian sebenarnya dengan disertai kriteria penilaian yang jelas.

Dalam penerapan model SAEPADU ini, peneliti melaksanakan dua siklus dengan dua kali pertemuan dan 1 kali kegiatan penilaian pada masing-masing siklus. Untuk melihat pelaksanaan pembelajaran dengan model SAEPADU dan motivasi belajar peserta didik, peneliti menggunakan lembar angket yang untuk melihat sejauh mana motivasi peserta didik dalam pelaksanaan proses pembelajaran. Selain itu peneliti juga mengadakan pengambilan data dengan intrumen tes dengan bentuk pilihan ganda untuk menggambarkan hasil belajar peserta didik untuk setiap siklusnya.

Dua siklus diterapkan peneliti untuk menjawab dan menyelesaikan masalah yang terjadi di kelas VIII E SMP Negeri 2 Bojongsari yang diperoleh berdasarkan hasil observasi awal. Kegiatan selanjutnya setelah observasi awal adalah melakukan perencanaan, pelaksanaan pembelajaran, proses observasi dan evaluasi, serta merefleksi kegiatan yang telah berlangsung. 
Penelitian tindakan kelas ini diakhiri apabila tercapainya indikator keberhasilan yang telah ditetapkan sebelumnya yaitu rata-rata hasil belajar peserta didik mencapai $85 \%$ dan data motivasi peserta didik minimal Baik (B).

\section{Hasil Siklus I}

Selama proses pembelajaran, orbserver melakukan proses observasi terhadap pelaksanaan kinerja guru dan peserta didik dalam pembelajaran IPA. Lembar observasi yang telah disiapkan digunakan untuk mengukur motivasi belajar peserta didik. Setelah melakukan pembelajaran pada Siklus I, peserta didik mengisi angket tentang motivasi yang telah diberikan. Hasil angket motivasi belajar dalam pembelajaran siklus I diperoleh hasil seperti grafik 2.

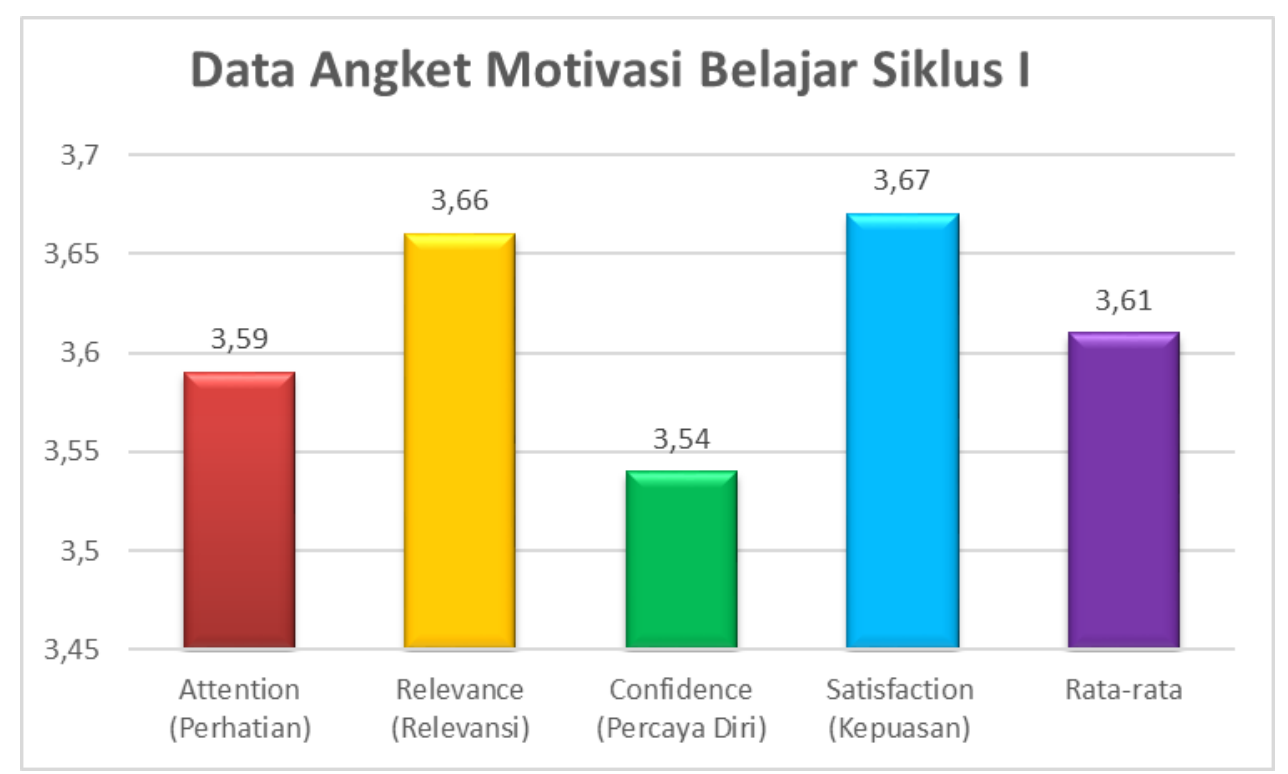

Gambar 2. Grafik Data motivasi Siklus I

Berdasarkan grafik di atas, motivasi peserta didik diperoleh rata-rata 3,62, yang menggambarkan bahwa motivasi peserta didik dalam pembelajaran dinilai baik namun masih di bawah tingkat meskipun faktanya telah terjadi peningkatan terhadap motivasi PraSiklus. Peneliti dalam siklus I juga melihat data hasil tes tertulis, sebanyak 14 peserta didik atau 46,67\% peserta didik telah mencapai KKM dengan nilai rata-rata 67,00. Pada Siklus I ini rata-rata nilai hariannya belum mencapai KKM yang ditentukan yaitu 70 serta secara klasikal masih ada 53,33\% yang belum sampai KKM, sehingga masih perlu di tingkatkan pada nilai rata-rata dan kelulusan secara klasikal.

Peneliti dengan observer melihat data-data dari hasil observasi yang dilakukan kemudian melakukan refleksi dan dihasilkan kesimpulan awal bahwa kinerja guru dalam proses pembelajaran sudah baik serta hasil motivasi belajar yang meningkat dibandingkan saat sebelum pelaksanaan siklus I. Walaupun nilai motivasi sudah tergolong baik namun peneliti menginginkan paling tidak rata-rata motivasi belajar mencapai nilai 4 dengan standar 5.

Sedangkan pada siklus I, hasil belajar peserta didik sudah mengalami peningkatan walaupun belum signifikan, dimana untuk rata-rata nilai tes tertulisnya baru 67,00 dengan 14 peserta didik atau 46,67\% yang mencapai nilai KKM. Hal ini sudah naik 13 peserta didik dibandingkan jumlah peserta didik yang mencapai nilai KKM pada pra siklus yaitu hanya 1 anak.

Berdasarkan hasil diskusi dan analisa dengan observer didapatkan hambatanhambatan dalam proses pembelajaran yaitu:

a. Belum tercapainya hasil motivasi belajar peserta didik dalam kategori nilai 4 dengan skala 5 . 
b. Masih adanya peserta didik yang belum menunjukkan motivasi dalam kerja kelompok maupun kerja individu dalam proses pembelajaran.

c. Masih ada dominasi peserta didik yang pandai bicara dalam proses diskusi dan presentasi dalam kelompok belajar di kelas.

d. Alokasi waktu yang diperhatikan guru sehingga ada proses yang belum selesai sehingga kegiatan pembelajaran kurang berjalan maksimal.

Berdasarkan hambatan dan kekurangan yang terdapat di atas nantikan akan diperbaiki dalam proses kegiatan pada siklus II.

\section{Hasil Siklus II}

Kegiatan dalam proses berikutnya mengacu pada desain pembelajaran yang telah direncanakan. Pada awal siklus II, peneliti memberikan pendahuluan berupa pemberian apersepsi, motivasi dan penyampaian tujuan pembelajaran, kemudian peserta didik dibagi menjadi beberapa kelompok yang heterogen seperti yang ada dalam perencanaan.

Dalam proses pembelajaran ini peneliti memberikan materi tekanan dari yang umum kemudian ke yang khusus baru menggunakan sintaks pembelajaran dengan model SAEPADU.

Observer melakukan proses pengamatan yang terjadi baik kegiatan yang dilakukan oleh peserta didik maupun kinerja guru di kelas. Kemudian peserta didik dibagikan angket untuk mengukur motivasi belajar dan pada akhir siklus diberikan penilaian tes tertulis dengan soal-soal yang memiliki tingkat pengetahuan dari $\mathrm{C} 1$ hingga $\mathrm{C} 5$ sesuai dengan materi yang guru telah ajarkan di kelas.

Secara umum proses pembelajaran yang dilakukan pada siklus II ini cenderung lancar dan peserta didik terlihat motivasinya dalam memperhatikan penjabaran materi yag guru sampaikan. Kinerja gurupun sudah jauh lebih bagus dibandingkan dengan siklus I. Suasana belajar di kelas juga menunjukkan gairah yang meningkat dalam proses yang dilakukan oleh guru maupun peserta didik.

Berdasarkan data angket motivasi yang telah diisi dihasilkan data perhatian, kepuasan, relevansi dan kepercayaan diri peserta didik tergambar dalam grafik berikut:

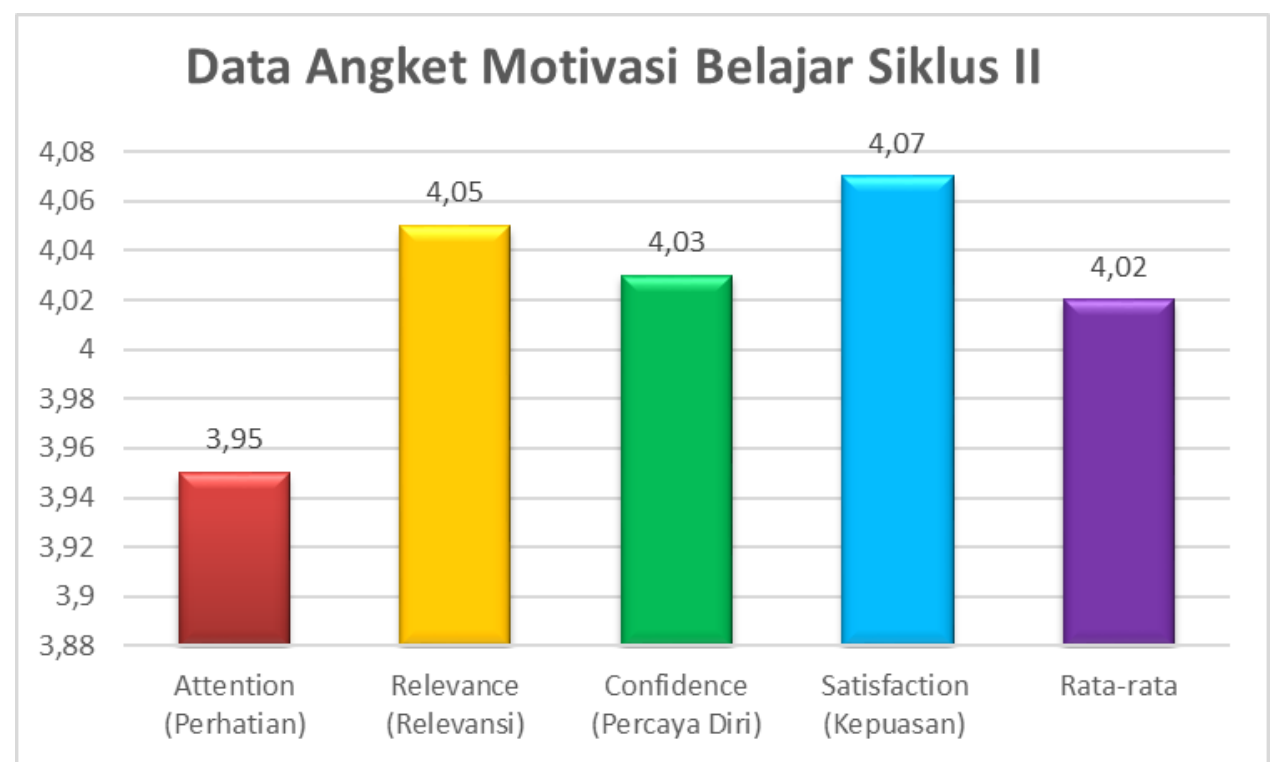

Gambar 3. Grafik Data motivasi Siklus II

Apabila dilihat pada grafik di atas dihasilkan bahwa motivasi belajar memiliki ratarata 4,02. Rata-rata ini menunjukkan bahwa peserta didik telah memiliki motivasi belajar yang masuk pada kategori baik, dengan hasil tersebut maka indikator keberhasilan yang telah direncanakan tercapai pada siklus II. Adapun hasil belajar yang didapatkan dari tes 
tertulis yang telah dikerjakan peserta didik pada siklus II ini, didapatkan hasil bahwa ratarata nilai ulangan IPA yaitu 76,50 dengan peserta didik yang lulus KKM mencapi 26 anak atau $86,67 \%$ dengan ambang tas KKM yaitu 70 . Seperti tertera pada tabel 1. berikut:

Tabel 1. Capaian Ketuntasan Nilai Tes Siklus II

\begin{tabular}{ccc}
\hline Indikator nilai & Jumlah peserta didik & Persentase \\
\hline$\geq$ KKM & 26 & $86,67 \%$ \\
\hline$<$ KKM & 4 & $13,33 \%$ \\
\hline
\end{tabular}

Berdasarkan hasil angket motivasi belajar dan hasil belajar dengan menggunakan tes tertulis serta memperhatikan data observasi dari observer didapatkan kesimpulan siklus II yaitu kemampuan peserta didik dalam proses pembelajatan IPA dengan model SAEPADU sudah berjalan dengan baik dibandingkan dengan siklus II. Kinerja guru dalam penerapan model ini juga telah sesuai dengan sintaks yang ada dan dibawakan dengan baik sehingga peserta didik terasa lebih termotivasi dalam pembelajaran IPA. Selain itu sebagai bentuk apresiasi pada peserta didik, guru juga memberikan penghargaan kepada kelompok yang paling aktif.

\section{Pembahasan}

Rendahnya motivasi dan hasil belajar peserta didik menjadi permasalahan dalam penelitian yang dilakukan oleh peneliti. Permasalahan tersebut dikarenakan guru belum memanfaatkan model pembelajaran yang diterapkan pada kurikulum dengan baik dalam proses membantu peserta didik dalam memahami pelajaran IPA. Oleh karena itu banyak peserta didik yang memberikan penilaian bahwa pelajaran IPA terasa lebih susah, tidak menarik untuk dipelajari dan cenderung membosankan, sehingga guru perlu memilih model pembelajaran yang lebih mudah diterima peserta didik untuk memecahkan permasalahan di atas. Salah satu model yang dapat digunakan dalam proses pembelajaran IPA dan tidak melenceng dari kurikulum yaitu dengan menerapkan model SAEPADU.

Penerapan model SAEPADU ini memberikan bantuan tersendiri bagi peserta didik dalam meningkatkan movitasi belajar sehingga peserta didik tersebut aktif di dalam kelompoknya maupun secara klasikal. Dengan aktifnya peserta didik harapannya pengetahuan yang didapatkan akan lebih masuk dalam memori secara jangka panjang sehingga konsepkonsep pembelajaran IPA akan lebih bertahan lama.

Hasil penelitian ini juga memberikan gambaran bahwa model SAEPADU ini merupakan pengembangan model yang mengupayakan penguasaan beberapa aspek dan kompetensi seperti penguasaan literasi, numerasi, komunikasi, kolaborasi serta menerapkan pembelajaran berpikir tingkat tinggi.

Dengan diterapkannya model SAEPADU pada pelaksanaan penelitian tindakan kelas ini berbanding lurus dengan peningkatan motivasi dan hasil belajar peserta didik, sehingga proses pembelajaran IPA dapat berjalan lebih bermakna bagi peserta didik.

Kelemahan yang dijumpai model SAEPADU adalah tidak semua peserta didik mampu menganalisis persoalan dalam kehidupan sehari-hari dengan menggunakan konsep tekanan sehingga memberikan peluang kepada peserta didik yang lebih pintar untuk mendominasi kelompoknya. Oleh karena itu diharapkan perlu ada pembagian kerja dalam kelompok agar tercipta kerjasama antar peserta didik sehingga kegiatan pembelajaran dengan model SAEPADU ini berjalan dengan lebih baik.

Adapun Permasalahan lain yang muncul dalam penerapan pembelajaran dengan model SAEPADU ini adalah pesserta didik hanya mengandalkan buku paket dan pendamping saja dalam mengeksplorasi pembelajaran berdasarkan studi literatur sehingga pembelajaran IPA pada konsep tekanan belum tereksplor lebih lanjut. Alhasil walaupun secara nilai sudah sampai KKM namun penguasaannya masih komprehensif. 


\section{a. Motivasi belajar peserta didik}

Berdasarkan hasil observasi dan perhitungan dari angket motivasi belajar peserta didik di dapatkan hasil bahwa pada saat pra siklus diketahui motivasi belajar peserta didik hanya mencapai rata-rata 3,39 dengan kategori Cukup. Setelah pelaksanaan siklus I penelitian tindakan kelas ini di dapatkan rata-rata motivasi belajar peserta didik mencapai 3,61 dengan kategori B. Sedangkan diakhir siklus II didapatkan hasil angket motivasi belajar sebesar 4,02 dengan kategori Baik dan telah mencapai indikator keberhasilan dalam penelitian tindakan kelas ini.

\section{b. Hasil belajar peserta didik}

Untuk hasil belajar peserta didik ini didapatkan dari hasil tes tertulis yang dilaksanakan pada saat sebelum kegiatan penelitian, kemudian akhir siklus I dan akhir siklus II. Berdasarkan hasil setelah melakukan setiap siklus dalam penelitian ini didapatkan bahwa adanya peningkatan rata-rata nilai ter tertulis IPA pra siklus dibandingkan pada siklus I yaitu 28,5 atau sebesar $76,62 \%$ dengan jumlah peserta didik yang lulus KKM mengalami peningkatan sebesar $43,34 \%$. Sedangkan untuk hasil rata-rata nilai ter tertulis IPA siklus I dibandingkan pada siklus II yaitu 9,5 sebesar $14,18 \%$. Sedangkan rata-rata peningkatan hasil belajar dari pra siklus ke siklus II terjadi kenaikan 98,70\%.

Berdasarkan hasil observasi, hasil belajar dan motivasi belajar peserta didik di atas tergambar jelas bahwa penelitian ini bermanfaat bagi guru dan peserta didik, seperti (1) peserta didik memperoleh pengetahuan dan keterampilan untuk mendapatkan pola pembelajaran baru yaitu proses analisis permasalahan, eksplorasi dengan studi literatur untuk pengembangan literasi, presentasi hasil dan duplikasi membuat peralatan sederhana yang menggunakan konsep tekanan dalam kehidupan sehari-hari, (2) motivasi belajar peserta didik meningkat, hal ini tergambar pada penilaian kepuasan, relevansi, kepercayaan diri dan perhatian peserta didik dalam proses pembelajaran seperti banyaknya yang melakukan proses bertanya, mengemukaan pendapat di depan kelas, berebut dalam presentasi, dan (3) belajar menjadi bermakna serta mampu membantu peserta didik dalam penguasaan literasi, numerasi, komunikasi, kolaborasi serta menerapkan pembelajaran berpikir tingkat tinggi.

Berdasarkan hasil penelitian tindakan ini relevan juga dengan penelitian yang dilakukan oleh Dywan (2020) yang menyatakan bahwa terdapat pengaruh pada keterampilan berpikir kritis siswa kelas IV SD Negeri Dukuh 01 Salatiga dan SD Negeri Kecandran 01 Salatiga dari kedua model pembelajaran yang digunakan yaitu model pembelajaran PJBL (Project based learning) berbasis STEM (Secience, Technology, Engineering, Mathemathic). Penelitian ini juga relevan dengan penelitian yang dilakukan oleh Murniasih (2018) tentang penggunaan model BARIUM berbantuan media Covalen pada materi tata nama senyawa pada peserta didik SMA Negeri 3 Malang. Model BARIUM adalah akronim dari 6 tahapan/sintaks pembelajaran, antara lain: Bringing something, Analyzing the problems, Reading the literatures, Integrating games and discussions, Using the concepts to solve the problems, dan Making conclusions.

\section{KESIMPULAN}

Berdasarkan data-data hasil observasi dan intrumen yang didapatkan dalam penelitian tindakan kelas yang dilakukan di kelas VIII E SMP Negeri 2 Bojongsari, Kabupaten Purbalingga tahun pelajaran 2019/2020 dapat disimpulkan bahwa: Adanya usaha peneliti untuk menggunakan model pembelajaran yang sesuai dengan materi yang berdampak pada berdampak peningkatan motivasi dan hasil belajar peserta didik. Dengan memanfaatkan pembelajaran dengan model SAEPADU ini dapat meningkatkan motivasi belajar peserta didik, yaitu sebesar 0,22 poin atau sekitar $6,49 \%$ dari pra siklus hingga siklus I dan pada siklus I ke di Siklus II juga terjadi peningkatan 0,41 poin atau $11,36 \%$. Dengan menggunakan pembelajaran dengan model SAEPADU ini juga dapat meningkatkan hasil belajar IPA pra siklus 
dibandingkan pada siklus I yaitu 28,5 atau sebesar 76,62\% dengan jumlah peserta didik yang lulus KKM mengalami peningkatan sebesar $43,34 \%$. Sedangkan untuk hasil rata-rata nilai ter tertulis IPA siklus I dibandingkan pada siklus II yaitu 9,5 sebesar 14,18\%.

\section{DAFTAR PUSTAKA}

Akpan, J. P., \& Beard, L. A. (2016). Using constructivist teaching strategies to enhance academic outcomes of students with special needs. Universal Journal of Educational Research, 4(2), 392-398.

Anonim. (2008). 21st Century Skills, Education \& Competitiveness: A Resource and Policy Guide.

Ariani, T. (2017). Penerapan Strategi Pembelajaran Ekspositori Untuk Meningkatkan Hasil Belajar Fisika. Jurnal Inovasi dan Pembelajaran Fisika, 4(1), 19-26.

Arsyad, Azhar. (2012). Perencanaan Pembelajaran. Bandung: PT. Remaja Rosdakarya

Aunurrahman. (2014). Belajar dan Pembelajaran. Bandung: Alfabeta

Brookhart, S. M. (2010). How to assess higher-order thinking skills in your classroom. ASCD. Dimyati dan Mudjiono. (2006). Belajar dan Pembelajaran. Jakarta: Rineka Cipta.

Dywan, A. A., \& Airlanda, G. S. (2020). Efektivitas Model Pembelajaran Project Based Learning Berbasis STEM dan Tidak Berbasis STEM terhadap Kemampuan Berpikir Kritis Siswa. Jurnal Basicedu, 4(2), 344-354.

Lailly, Nur Rochmah and Wisudawati, Asih Widi. (2015). Analisis Soal Tipe Higher Order Thinking Skill (Hots) Dalam Soal UN Kimia SMA Rayon B Tahun 2012/2013. Kaunia Jurnal Sains dan Teknologi, Vol.11 (No. 1). pp. 27-39. ISSN 2301-8550.

Lilies. (2015). Strategi ARCS dalam Pembelajaran Biologi untuk Meningkatkan Motivasi Belajar siswa. Prosiding. Seminar Nasional Sains dan Matematika Jurusan Pendidikan MIPA FKIP UNTAD.

Monika, M., \& Adman, A. (2017). Peran Efikasi Diri dan Motivasi Belajar dalam Meningkatkan Hasil Belajar Siswa Sekolah Menengah Kejuruan. Jurnal Pendidikan Manajemen Perkantoran, 1(1), 110-117

Murniasih, Luh. (2018). Pengembangan Model Pembelajaran Barium Berbantuan Media Carolen Pada Materi Tata Nama Senyawa. Malang: Laporan Penelitian.

Sagala, Syaiful. (2009). Konsep dan Makna Pembelajaran. Bandung: CV. ALFABETA.

Sardiman, AM. (2001). Interaksi dan Motivasi Belajar Mengajar. Jakarta: PT. Raja Grafindo Persada

Sears, Susan. (2002). Contextual Teaching And Learning A Primer For Effective Instruction.United States of Amerika.

Slameto. (2003). Belajar dan Faktor-Faktor yang Mempengaruhinya. Jakarta: PT Rineka Cipta.

Suciati, et. al. (1996). Teori Belajar, Motivasi dan Keterampilan Mengajar. Jakarta: PAUPPAI.

Sudjana, Nana. (2009). Penilaian Hasil Proses Belajar Mengajar. Bandung: Remaja Rosdakarya.

Supriyadi. (2010). Teknologi Pembelajaan Fisika. Yogyakarta: FMIPA Universitas Negeri Yogyakarta.

Surya, M. (2014). Psikologi Guru: Konsep dan Aplikasi. Bandung: Alfabeta

Trianto. (2011). Model Pembelajaran Terpadu Konsep, Strategi Dan Implementasinya Dalam Kurikulum Tingkat Satuan Pendidikan (KTSP). Jakarta: Bumi Aksara.

Trilling, B., \& Fadel, C. (2009). 21 st century skills: Learning for life in our times. John Wiley $\&$ Sons.

Wardani. (2002). Penelitian Tindakan Kelas. Jakarta: Universitas Terbuka.

Winarni, M., Anjariah, S., \& Romas, M. Z. (2016). Motivasi Belajar Ditinjau Dari Dukungan Sosial Orangtua Pada Siswa SMA. Jurnal Psikologi, 2(1). 